Він пахне затишно домівкою моєю.

Окрім годин спілкування, екскурсій, подорожей, задля формування професійної спрямованості майбутніх гірничих інженерів доцільно реалізувати форми та методи роботи, які передбачали б ознайомлення «з реальним виробничим процесом, особливостями професійної діяльності сучасного гірничого інженера - лекції-екскурсії на кар'єри»; бесіди «Історія нашого факультету», «Мій ВН3 - найкращий»; зустрічі з випускниками, які досягли успіхів у професії [5, с. 155], дискусії тощо.

Отже, профорієнтаційна робота повинна бути невід'ємною частиною освітнього процесу вищого навчального закладу й обов'язково спрямована на формування професійної спрямованості майбутніх гірничих інженерів. Перспективи подальших розвідок убачаємо у висвітленні змісту профорієнтаційної роботи в системі «школа - ВНЗ - підприємство».

\title{
Література:
}

1. Александрова С. Чим пахне Кривий Ріг [Електронний ресурс] / Світлана Александрова. - Режим доступу: http://m.0564.ua/news/842857 2. Бондаренко О. В. Структура готовності майбутніх гірничих інженерів до професійної діяльності / О. В. Бондаренко // Проблеми сучасної педагогічної освіти. Сер. Педагогіка і психологія: зб. статей. - Вип. 45. Ч. 4. - Ялта : РВВ КГУ, 2014. - С. 45-51. 3. Браташ О. Проблеми і розвиток вищої гірничої освіти [Електронний ресурс]/ О. Браташ. - Режим доступу: http://ea.dgtu.donetsk.ua:8080/jspui/ bitstream/ 123456789/ 7279/1 4. Включення випускників гірничо-металургійних спеціальностей до професійно-економічної сфери суспільства (Дніпропетровський регіон): [монографія]/ Д. В. Колісник, М. В. Мосьондз, Л. О. Колісник. - Дніпропетровськ : НГУ, 2015. - 87 с. 5. Дерев'янко О. В. Формування професійної компетентності майбутніх гірничих інженерів у процесі навчання фахових дисциплін: дис. на здобуття наук. ступеня канд. пед. наук : 13.00 .04 / Дерев'янко Олена Василівна. - Житомир, 2014. - 387 с. 6. Моркун В. С. Підготовка гірничого інженерна: школа - ВН3 - підприємство: [монографія] / В. С. Моркун, 3. П. Бакум, С. М. Хоцкіна, В. В. Ткачук. - Кривий Ріг: Видавничий центр ДВНЗ «КНУ», 2015. - 244 с. 7. Наказ Президента України «Про Національну стратегію розвитку освіти в Україні на період до 2021 року» [Електронний ресурс]. - Режим доступу : http://zakon3.rada.gov.ua/laws/show/ $344 / 2013$

УДК 371.134

Ірина Онищенко

\section{НАВЧАЛЬНО-ПРОФЕСІЙНА МОТИВАЦІЯ ЯК СКЛАДНИК ПРОФЕСІЙНОГО СТАНОВЛЕННЯ МАЙБУТНІХ ФАХІВЦІВ ПЕДАГОГІЧНОГО ПРОФІЛЮ}

Онищенко I. В. Навчально-професійна мотивація як складник професійного становлення майбутніх фахівців педагогічного профілю.

У статті розкрито сутність поняття «навчально-професійна мотивація», іiі ознаки, структура та роль у професійному становленні майбутніх фахівців педагогічного профілю. Визначено, що навчально-професійна мотивація охоплює інтеграцію спонукань, пов'язаних із навчальною та професійною діяльністю, на основі взаємних трансформацій пізнавальних i професійних мотивів. Проаналізовано соціально-психологічні особливості навчальнопрофесійної мотивації майбутніх педагогів, розкрито умови іï формування в умовах ВНЗ. Обгрунтовано, що навчально-професійна мотивація $\epsilon$ внутрішнім рушійним чинником формування професіоналізму, провідним чинником успішного навчання у ВНЗ.

Ключові слова: мотив, мотивація, навчально-професійна мотивація, навчальна діяльність, професійна діяльність, професійна підготовка, професійне становлення, педагог.

Онищенко И. В. Учебно-профессиональная мотивация как составляющая профессионального становления будущих специалистов педагогического профиля.

В статье раскрыта сущность понятия «учебно-профессиональная мотивация», ее 
признаки, структура и роль в профессиональном становлении будущих специалистов педагогического профиля. Определено, что учебно-профессиональная мотивация включает интеграцию побуждений, связанных с учебной и профессиональной деятельностью, на основе взаимных трансформаций познавательных и профессиональных мотивов. Проанализированы социально-психологические особенности учебно-профессиональной мотивации будущих педагогов, раскрыты условия ее формирования в условиях вуза. Обосновано, что учебно-профессиональная мотивация является внутренним движущим фактором формирования профессионализма, ведущим фактором успешного обучения в вузе.

Ключевые слова: мотив, мотивация, учебно-профессиональная мотивация, учебная деятельность, профессиональная деятельность, профессиональная подготовка, профессиональное становление, педагог.

Onishchenko I. V. Educational and professional motivation as a part of professional formation of future specialists of pedagogical specialization.

The interest in teaching profession and its development is one of the important factors of successful learning and future professional self-development. Educational and professional motivation is important in teacher's professiogram. The aim of the article is to analyse the sociopsychological characteristics of educational and professional motivation for future pedagogical specialists, define the role of educational and professional motivation in the system of future teachers training. Research methods are the analysis of state standards, statistics and scientific publications. Analyzed social-psychological characteristics of educational and professional motivation of future teachers showed the conditions of its formation in terms of high school. Educational and professional motivation requires integration, interests, incentives, values and motivations which encourage and guide person in msatering future profession. The direction of development and transformation of the motivational structure of students' personality formation during the educational process is determined by the number of specific factors, such as educational system, educational institutions, organization of educational process, personal characteristics of students, personal characteristics of teachers, specific academic subjects. It was proved that educational and professional motivation is the internal driving factor of professionalism formation and a leading factor in successful learning at secondary school.

Formation of educational and professional motivation of future specialists of pedagogical specialization is an essential component of training. It provides students with fundamental knowledge, professional skills, active, conscious affirmation of professional choice. Educational and professional motivation is a dynamic system that changes according to the stages of professional development of the individual. Training of teachers must make the transition from teaching and learning to the professional development with corresponding changes in motivations, goals, means, subjects and results. Prospects for further research are aimed at studying the place of motivational component in the structure of readiness of the future teacher to innovative professional activities.

Key words: motive, motivation, educational and professional motivation, learning activities, professional activities, professional training, professional development and teacher.

Важливим завданням сучасної вищої освіти є підготовка фахівця, мотивованого на отримання високопрофесійних знань, набуття професійних компетенцій та професійну самореалізацію. Проблеми професійного самовизначення, розвитку професійної самосвідомості, самоідентифікації та професійної мотивації в освітньому процесі вищої школи останнім часом набувають особливої актуальності.

Інтерес до професії педагога та її опанування є одним із важливих чинників успішного навчання й майбутнього професійного самовдосконалення. У цьому контексті формування навчально-професійної мотивації студентів у ВНЗ може стати критерієм і однією 3 компетенцій, на основі якої можна схарактеризувати рівень професійної підготовки в університеті. Студент, професійно визначаючись, надає перевагу певним видам діяльності, у 
яких найповніше може реалізувати свої здібності, потреби й життєві плани. Важливо, щоб сучасний студент умів аналізувати зміст мотивації своєї навчально-професійної діяльності, співвідносив різні мотиваційні спонуки та був активним творцем розглядуваної мотивації. Уважаємо, що успішним у навчанні буде той студент, який усвідомлює гостру потребу в знаннях, уміннях, навичках, необхідних для майбутньої професійної діяльності.

Хоча передбачається, що під час вступу до ВНЗ студенти роблять усвідомлений вибір, але дослідження свідчать, що нині лише близько $25 \%$ абітурієнтів професійно мотивовані. Отже, формування позитивного ставлення до професії $€$ актуальною проблемою вищої професійної освіти. При цьому важливим є визначення змісту та форм освіти, що сприяють вибудовуванню майбутніми фахівцями мотивації навчально-професійної діяльності у ВНЗ, яка поступово перейде у професійну діяльність.

Мотивація є однією 3 фундаментальних проблем як для вітчизняної, так $\mathrm{i}$ для зарубіжної психології та педагогіки. Ї̈̈ значущість для освітньої практики настільки вагома, що інтерес і увага науковців до різних аспектів цієї проблеми не применшується протягом багатьох десятиліть. В останні роки з'явилася значна кількість досліджень, присвячених проблемі формування у студентів навчальної та професійної мотивації. Теоретикометодологічну основу цих досліджень складають класичні праці вітчизняних і зарубіжних психологів $з$ психології мотивації (Б. Ананьєв, Дж. Аткінсон, Л. Божович, А. Леонтьєв, А. Маслоу, Г. Мюррей, В. М'ясищев, Ж. Нюттен, С. Рубінштейн, Х. Хекхаузен, П. Якобсон та ін.). Новий імпульс ці дослідження отримали у зв'язку з розробленням в сучасній психологічній науці категорії ціннісно-смислового складника мотиваційної сфери особистості в цілому і мотивації навчання зокрема (А. Бодальов, Г. Вайзер, А. Деркач, Д. Леонтьєв, С. Мартинова, Л. Мітіна, В. Франкл, В. Чудновський).

Вивченню різних регуляторів поведінки людини і іiї професійної діяльності присвячені дослідження А. Здравомислова, Н. Захарова, Н. Іванчука, А. Леонтьєва, Д. Узнадзе, В. Ядова та ін. Психологічні аспекти мотивації і стимулювання трудової діяльності, професіогенеза особистості, формування професійної кар'єри знайшли відображення в працях К. Абульханової-Славської, А. Аверіна, Л. Азямової, К. Андреєва, В. Асєєва, Л. Виготського, Ю. Забродіна, Д. Завалишиної, В. Ігнатова, С. Рубінштейна та ін.

У вітчизняній педагогіці та психології велика увага приділяється різним аспектам професійного становлення майбутніх фахівців, зокрема, дослідженню студента як суб'єкта діяльності, етапів та чинників становлення його як професіонала (К. Абульханова-Славська, В. Бодров, Е. Клімов, А. Маркова, А. Деркач, В. Шадриков та ін.), визначенню здібностей, можливостей, спрямованості, індивідуально-особистісних особливостей, необхідних для формування професійно важливих якостей особистості студента у процесі його навчання (Е. Зеєр, Є. Климов, Т. Кудрявцева, Б. Ломов, Б. Теплов та ін.).

Мотиваційно-потребнісні компоненти навчальної та навчально-професійної діяльності розглядалися багатьма вітчизняними та зарубіжними науковцями (В. Апельт, Л. Божович, Р. Вайсман, Л. Виготський, I. Ільїн, В. Кікоть, А. Леонтьев, Г. Мухіна, Н. Нестерова, С. Рубінштейн, А. Печніков, Г. Щукіна, П. Якобсон, В. Якунін та ін.).

Водночас практично відсутні спеціальні дослідження, присвячені вивченню соціально-психологічних особливостей навчально-професійної мотивації майбутніх фахівців педагогічного профілю, що становить актуальність статті.

Мета статmі - розглянути соціально-психологічні особливості навчально-професійної мотивації майбутніх фахівців педагогічного профілю, визначити роль навчально-професійної мотивації в системі професійної підготовки майбутніх педагогів.

Складність, багатоаспектність, теоретична і практична значущість проблеми мотивації зумовлює численність підходів до розуміння пї сутності. В енциклопедичній літературі знаходимо різні тлумачення поняття «мотивація», зокрема розглядуване поняття трактується як «спонука, що викликає активність організму та визначає іiї спрямованість» [4, с. 190], «усвідомлювані або неусвідомлювані психічні чинники, що спонукають індивіда до здійснення певних дій і визначають їхню спрямованість та цілі» [6, с. 264], «сукупність 
стійких мотивів, спонук, що визначають зміст, спрямованість і характер діяльності особистості, iii поведінки» [5, с. 81] та ін. Отже, мотивація охоплює сукупність внутрішніх і зовнішніх рушійних сил, які спонукають людину до діяльності, визначають поведінку, форми діяльності, надають цій діяльності спрямованості, зорієнтованої на досягнення певних цілей.

У психології виокремлюють внутрішню і зовнішню мотивацію педагогічної діяльності (К. Замфір, М. Овчинников, А. Реан та ін.). Ми приєднуємося до думки Р. Бібріха, Д. Ельконіна, О. Леонтьєва, В. Ляудис, А. Маркової, Л. Мітіної та ін., згідно з якою внутрішня мотивація безпосередньо пов'язана з самою діяльністю. Вона реалізує пізнавальну потребу i має для особистості ціннісний зміст. За допомогою внутрішньої мотивації реалізується потреба людини у внутрішньому благополуччі, гармонізації внутрішнього світу, самовдосконаленні й самоактуалізації. Зовнішні мотиви диференціюються на зовнішні позитивні і зовнішні негативні (К. Замфір, А. Реан та ін.). Зовнішня позитивна мотивація пов'язана із задоволенням потреб соціального престижу, поваги колег, матеріальних благ і т.і., зовнішня негативна мотивація - 3 потребою самозахисту, прагненням уникнути осуду з боку дирекції тощо.

У працях М. Бакунович, Р. Бібриха, С. Богданович, А. Бугрименко, Є. Кринчик, Д. Меламеда, М. Овчинникова, В. Соніна та ін., присвячених проблемі динаміки мотивації навчання і професійної діяльності студентів педагогічних вишів, підкреслюється, що провідним видом діяльності студентів є навчально-професійна діяльність.

На нашу думку, одним із провідних чинників успішного навчання у ВН3, рушійною силою, яка спонукає студентів оволодівати будь-якою професією, зокрема професією педагога, є навчально-професійна мотивація. Уважаємо, що доцільно говорити не про навчальну мотивацію і не про професійну мотивацію, а саме про навчально-професійну мотивацію студента. Адже саме в останній закладена професійна спрямованість і готовність майбутнього педагога до розв'язання професійних завдань. Аналіз досліджень Л. Захарової, Н. Кузьміної, Ю. Кулюткіна, Н. Левітова, А. Маркової, Л. Митіної, А. Реана, В. Сластьоніна, Г. Сухобської, А. Щербакова та ін. засвідчує, що навчально-професійна мотивація займає важливе місце у професіограмі педагога.

Під навчально-професійною мотивацією ми розуміємо сукупність чинників і процесів, які спонукають і спрямовують особистість до опанування майбутньої професійної діяльності. Навчально-професійна мотивація $є$ внутрішнім рушійним чинником формування професіоналізму та особистості в цілому. При цьому мотиви професійної діяльності розглядаються як усвідомлення предметів актуальних потреб особистості (одержання вищої освіти, саморозвитку, самопізнання, професійного розвитку, підвищення соціального статусу), що задовольняються за допомогою виконання навчальних завдань і спонукають іiї до вивчення майбутньої професійної діяльності.

I. Нікітіна, В. Мартич уважають, що внутрішнім спонукальними чинником професіоналізму майбутнього фахівця, його продуктивної професійної діяльності $\epsilon$ професійна мотивація, яку трактують як «сукупність чинників і процесів, які, відбиваючись у свідомості, спонукають особистість до вивчення та ефективної реалізації майбутньої професійної діяльності». Іншими словами, професійна мотивація є внутрішнім рушійним чинником розвитку професіоналізму особи, оскільки лише на основі формування ії високого рівня можлива продуктивна професійна діяльність [7, с. 208].

Формування конкурентоспроможного фахівця потребує такої організації навчального процесу, що забезпечить перехід від навчально-пізнавальної діяльності до професійної 3 відповідною зміною потреб і мотивів, цілей, засобів, предмета і результатів.

М. Лях, спираючись на класифікацію мотивів навчання школярів, запропоновану А. Марковою [6], виокремлює дві групи мотивів навчально-професійної діяльності у ВНЗ: 1) навчально-професійні мотиви; 2) соціально-професійні мотиви. Кожна 3 цих груп має відповідно три види мотивів [5]. Група навчально-професійних мотивів охоплює такі мотиви: 1) широкі навчально-професійні мотиви (прагнення студента у процесі навчання отримати глибокі професійні знання); 2) вузькі навчально-професійні мотиви (прагнення 
студента оволодіти способами набуття професійних знань, необхідних для майбутньої професії - навчитися вчитися у ВН3); 3) мотиви професійної самоосвіти (прагнення студента оволодіти способами самостійного поповнення знань, необхідних для майбутньої професійної діяльності). Група соціально-професійних мотивів охоплює: 1) широкі соціально-професійні мотиви (прагнення оволодіти професію, яка необхідна і важлива для сучасного суспільства); 2) вузькі соціально-професійні мотиви (прагнення студента зайняти певне місце в суспільстві- диплом, престиж); 3) мотиви професійного співробітництва (прагнення студента спілкуватися з людьми, у яких подібні 3 ним професійні інтереси і захоплення). Кожен з трьох видів мотивів у своїй групі може бути також розглянутий як відповідний рівень сформованості мотивації навчально-професійної діяльності студентів [5].

Отже, вихідними у формуванні навчально-професійної мотивації постають широкі навчально-професійні мотиви, потім - вузькі навчально-професійні мотиви, і вищим рівнем у цій групі мотивів $є$ мотиви професійної самоосвіти. У групі соціально-професійних мотивів вихідний рівень утворюють широкі соціально-професійні мотиви, що переходять у вузькі соціально-професійні мотиви, і завершують становлення цієї групи мотиви професійної співпраці.

Успішне розв'язання завдань вищої освіти вимагає з'ясування факту домінування в мотиваційному профілі студента того чи того виду навчально-професійної мотивації (зовнішньої або внутрішньої). Так, дослідження А. Бугрименко показало, що навчальнопрофесійна діяльність внутрішньо і зовні мотивованих студентів педагогічного вишу істотно різниться. Зокрема, внутрішньо мотивовані студенти більш занурені в навчальний процес. Вони більш активні, свідомі, довільні у плануванні своєї професійної освіти; однакову увагу приділяють як загальноосвітнім, так і вузькопрофесійним предметам. Студенти, у яких переважає зовнішня мотивація, меншою мірою занурені в навчальне середовище, оскільки ними рухають не стільки пізнавальні або професійні мотиви, скільки зовнішні стосовно процесу і результату навчальної діяльності чинники [1].

В. Дуб, І. Галян уважають, що мотивація навчально-професійної діяльності студентів $\epsilon$ сукупністю пізнавальних, соціальних, професійних мотивів та основною причиною зацікавленого ставлення до навчання як основи професійної діяльності. Зокрема, пізнавальні мотиви визначають прагнення досконалого володіння знаннями, уміннями й навичками професійної діяльності; соціальні мотиви виявляються в самоствердженні, у виявленні свого соціального статусу у навчанні; професійні мотиви виявляються у прагненні до оволодіння обраною професією. Науковці визначили сукупність чинників, які визначають активність особистості в галузі професійної діяльності та спонукають студентів до оволодіння педагогічним мистецтвом, зокрема: 1) ставлення до майбутньої педагогічної діяльності, 2) зацікавленість професійною діяльністю, 3) активність у досягненні навчальних результатів. За наявності саме цих складників мотивації, на думку дослідників, студенти зазвичай прагнуть постійного розвитку креативності, спрямованого на отримання нового знання і формування професійно важливих якостей, які є основою фахової компетентності майбутнього педагога [3, с. 418].

Як показують результати теоретико-емпіричних досліджень, серед компонентів навчально-професійної мотивації студентів можна виокремити два класи мотивів: 1) центральні мотиви - мотиви, що спрямовані на процес і результати освіти (навчальнопізнавальні, професійні мотиви, мотиви самореалізації); 2) супутні професіоналізації студентів, або зовнішні стосовно процесу та результатам освіти мотиви (мотиви комунікативні, уникнення, престижу, соціальні). Залежно від стадії соціальнопсихологічного розвитку особистості і групи у процесі вишівської освіти, а також положення студентів у структурі міжособистісних відносин профіль навчально-професійної мотивації майбутніх фахівців набуває різних характеристик.

Уважаємо, що успішному формуванню навчально-професійної мотивації в майбутніх фахівців педагогічного профілю сприяють такі умови: 1) ознайомлення студентів із сучасними вимогами до професійно-предметних компетенцій майбутнього фахівця; 
2) забезпечення здобуття студентами теоретичних знань та набуття практичних навичок 3 обраного фаху на різних етапах навчання; 3) створення навчально-професійного середовища у ВНЗ та забезпечення сприятливої навчально-професійної творчої атмосфери в ньому; 4) орієнтація навчально-виховного процесу на професійний саморозвиток студентів (самопізнання, самовизначення, самоорганізація, самореалізація); 5) організація різноманітних видів практик, що сприяють поглибленню, узагальненню і вдосконаленню студентами теоретичних знань, набутого професійного досвіду, формуванню професійних умінь і навичок, компетенцій та підготовці до самостійної трудової діяльності; 6) виконання системи різноманітних дій з мотивами навчально-професійної діяльності (дії аналізу власної мотивації; дії співвіднесення мотивів, що складають навчально-професійну мотивацію; дії конструювання мотивації фахової діяльності).

Погоджуємося $з$ думкою Є. Бухтєєвої, О. Кравець, які підкреслюють, що важливу роль у формуванні мотивації до професійної діяльності $є$ особистість викладача, його професійна компетентність (спеціальна, соціальна, особистісна, індивідуальна), яка полягає у володінні власне професійною діяльністю на досить високому теоретичному і практичному рівнях, здатності віднаходити нестандартні рішення, проектувати подальше професійне самовдосконалення, ставити i реалізовувати завдання індивідуального психологічного саморозвитку [2, с. 40]. Сучасний викладач повинен бути ознайомлений 3 новітніми освітніми технологіями і пропонувати студенту великий вибір активних методів: проблемне навчання, ігрові технології, тренінгові технології, метод проектів та ін. Ці методи не тільки розвивають творчий та інтелектуальний потенціал студентів, але й надають змогу розв'язувати актуальні проблеми, практичні завдання [10, с. 211-212]. Система наведених педагогічних умов створює сприятливий мікроклімат для формування навчальнопрофесійної мотивації, позитивного ставлення до обраної професії, інтересу до педагогічного фaxy.

Отже, навчально-професійна мотивація $є$ інтеграцію потреб, інтересів, стимулів, настанов, ціннісних орієнтацій і мотивів, які спонукають і спрямовують особистість до опанування майбутньої професії. Навчально-професійна мотивація майбутніх фахівців визначається низкою специфічних для цієї діяльності чинників: освітньою системою, освітнім закладом, організацією освітнього процесу, особистісними особливостями студента, особистісними особливостями педагога, специфікою навчальних предметів. Формування навчально-професійної мотивації майбутніх фахівців педагогічного профілю є невід'ємним компонентом професійної підготовки. Високий рівень сформованості навчально-професійної мотивації студентів $\epsilon$ критерієм i однією 3 компетенцій, на основі якої можна схарактеризувати рівень професійної підготовки в університеті. Перспективи подальших досліджень спрямовані на вивчення місця мотиваційного компонента у структурі готовності майбутнього педагога до інноваційної професійної діяльності.

\section{Література}

1. Бугрименко А. Г. Внутренняя и внешняя учебная мотивация у студентов педагогического вуза [Электронный pecypc]/ А. Г. Бугрименко. - Режим доступа: http://www.psyjournals.ru. 2. Бухтеева Е. Е. Педагогические условия формирования мотивации к профессиональной деятельности / Е. Е. Бухтеева, О. И. Кравец // Среднее профессиональное образование. - 2013. - № 2. - С. 39-41. 3. Дуб В. Г. Навчально-професійна мотивація майбутніх педагогів як складова їх професійного становлення/ В. Г. Дуб, I. М. Галян // Науковий вісник Львівського державного університету внутрішніх справ. 2012. - № 2. - С. 415-423. 4. Краткий психологический словарь / под ред. А. В. Петровского, М. Г. Ярошевского. - Ростов-на-Дону: Феникс, 1998. - 505 с. 5. Лях М. В. Особенности развития мотивов учебно-профессиональной деятельности в студенческом возрасте [Электронный ресурс] / М. В. Лях // Психологическая наука и образование: электронный журнал. - 2011.- № 4.- Режим доступа: psyjournals.ru/.../ psyedu_ru_2011_4_Lyakh 6. Маркова А. К. Формирование мотивации учения: [книга для учителя] / А. К. Маркова, Т. А. Матис, А. Б. Орлов. - Москва : Просвещение, 1990. - 192 с. 7. Нікітіна І. В. 
Формування професійної мотивації студента як детермінанти його творчого розвитку i працевлаштування / I. В. Нікітіна, В.В.Мартич // Вісник Національного технічного університету України «Київський політехнічний інститут». Філософія. Психологія. Педагогіка. - 2010. - № 1 (28). - C. 206-211. 8. Словарь-справочник практического психолога / под ред. Н. И. Конюхова. - Воронеж : МОДЭК, 1996. - 224 с. 9. Современные образовательные технологии: [учеб. пособ.] / под ред. Н. В. Бордовской. - Москва : КРОНУС, 2010. - 432 с. 10. Сучасний тлумачний психологічний словник : [близько 2500 термінів / уклад. В. Б. Шапар]. - Харків : Прапор, 2007. - 640 с.

\title{
ДО ПРОБЛЕМИ ОРГАНІЗАЦЇ̈ ІНДИВІДУАЛЬНОЇ НАВЧАЛЬНО- ДОСЛІДНИЦЬКОЇ ДІЯЛЬНОСТІ СТУДЕНТІВ
}

\begin{abstract}
Соболєва С. М. До проблеми організації індивідуальної навчально-дослідницької діяльності студентів.

У статті здійснено аналіз якості виконання студентами індивідуальних навчальнодослідницьких завдань, як одного з важливих видів самостійної роботи; визначено основні причини низької результативності навчально-дослідницької діяльності, такі, як: недостатній рівень базових знань із предметів шкільного курсу, академічна прокрастинація, низький рівень інформаційної культури студентів та відсутність навчальної мотивації. Запропоновано найбільш ефективні методи підвищення мотивації, організації та управління навчальнодослідницькою діяльністю студентів.
\end{abstract}

Ключові слова: самостійна робота студента, навчально-дослідницька діяльність, індивідуальне навчально-дослідницьке завдання, проект, проектна діяльність, коучинг, педагогічний коучинг, коучингові технології.

Соболева С. М. К проблеме организации индивидуальной учебно-исследовательской деятельности студентов.

В статье анализируется качество выполнения студентами индивидуальных учебноисследовательских заданий, как одного из важных видов самостоятельной работы; выделяются основные причины низкой результативности учебно-исследовательской деятельности, такие как: недостаточный уровень базовых школьных знаний, академическая прокрастинация, низкий уровень информационной культуры студентов и отсутствие учебной мотивации. Предложены наиболее эффективные методы повышения мотивации, организации и управления учебно-исследовательской деятельностью студентов.

Ключевые слова: самостоятельная работа студента, учебно-исследовательская деятельность, индивидуальное учебно-исследовательское задание, проект, проектная деятельность, коучинг, педагогический коучинг, коучинговые технологии. activities.

Sobolyeva S. M. The organization issue of students' individual educational and research

The role of individual work of students, including individual research tasks, in training highqualified specialists and forming quality of education is considered in the article. The essence of the concept of individual educational and research tasks as a form of extracurricular individual work of student, which has educational, research or design nature, has been used in the educational course and based on the searching and analyzing of certain parts of the discipline material, its systematization, synthesis. Attention is paid to the peculiarities of educational and research activity of student in higher education as a form of creative work.

The quality of students' individual research tasks has been analyzed. The results of pedagogical research have identified the main causes of low quality tasks, such as insufficient basic knowledge of subjects school course, academic procrastination, low information culture of students 